\title{
Phenolic compounds variation in Mentha $L$. species in the course of a four-years period Kolísanie fenolových látok $v$ rôznych druhoch Mentha L. počas 4 ročného obdobia
}

Abstract Mints rank among the most important Lamiaceae plants. In addition to essential oil, they contain many valuable phenolic compounds, including flavonoids and phenolic acids that participate in mints' pharmacological properties. In this work, we examined the contents of phenolic compounds variation in the course of 4 years of vegetation. We compared the contents of total hydroxycinnamic derivatives expressed as rosmarinic acid $(\lambda=505 \mathrm{~nm})$, total polyphenols and tannins expressed as rosmarinic acid $(\lambda=760 \mathrm{~nm})$, and flavonoids expressed as luteolin-7-O-glucoside $(\lambda=392 \mathrm{~nm})$ and quercetin $(\lambda=420 \mathrm{~nm})$ in 1-, 2-, $3-$, and 4-year-old plants' dry leaves, respectively. Spectrophotometric methods of the European Pharmacopoeia were employed. Our results show high levels of active phenolic compounds, particularly in 3-and 4-year-old plants.

Slovak Mäty patria medzi významné rastliny čelade Lamiaceae. Okrem silice obsahujú množstvo cenných fenolových látok, vrátane abstract flavonoidov a fenolových kyselín, ktoré sa spolupodielajú na farmakologickej aktivite mäty. V našej práci sme hodnotili kolísanie obsahu fenolových látok počas 4 rokov vegetácie. Pri 1- až 4-ročných rastlinách sme porovnali v suchých listoch obsah hydroxyškoricových derivátov vyjadrených ako kyselina rozmarínová $(\lambda=505 \mathrm{~nm})$, polyfenolov a trieslovín vyjadrených ako kyselina rozmarínová $(\lambda=760 \mathrm{~nm})$ a flavonoidov vyjadrených ako luteolín-7-O-glukozid $(\lambda=392 \mathrm{~nm})$ a kvercetín $(\lambda=420 \mathrm{~nm})$. Využili sme spektrofotometrické metódy Európskeho liekopisu. Naše výsledky poukazujú na vysoké hodnoty fenolových látok najmä v 3- a 4-ročných porastoch.

Keywords Mentha-THD-total polyphenols-tannins-flavonoids-age of plants

Klúčové Mentha-THD-celkové polyfenoly-triesloviny-flavonoidy-vek rastlín slová:

\section{INTRODUCTION}

The species of the genus Mentha L. of the family Lamiaceae belong to the most conventional medicinal plants worldwide. Lawrence et al. (2007) have reviewed the published literature about mints. The genus comprises 18 species and about 11 hybrids placed in 4 sections, of which, the most popular and used are the members of the section Mentha, especially the hybrid $M$. $\times$ piperita. Peppermint has been reported to possess these biological activities: digestive, cholekinetic, choleretic, antispasmodic, antibacterial, antiviral, fungicidal, antioxidant, anti-inflammatory, expectorant, myorelaxant, analgesic as well as insecticidal, aphrodisiac, local anaesthetic, antiemetic, antiulcer, astringent, vasodilating, etc. (Duke et al., 2002; Mckay \& Blumberg, 2006; Koštálová et al., 2012). Spearmint (M. spicata) leaves are more commonly used for culinary purposes, but they possess antimicrobial, antioxidant, stimulant, antispasmodic and carminative effects (Lawrence et al., 2007). An antimicrobial and antioxidant effect was proven within many different mints (Gulluce et al., 2007; Fialová et al., 2008; Fialová et al., 2012). The pharmacological effects of mints are chiefly bound to the presence of two main groups of secondary metabolites: essential oil and phenolic compounds. The essential oil of mints is composed of monoterpenes and sesquiterpenes, and the content proportion of these groups' compounds varies from species to species. The main phenolic compounds in mints are phenolic acids (especially rosmarinic acid) and flavonoids (eriodictyol, luteolin, apigenin and their glycosides). 
Recently, several studies dealing with changes in essential oil composition depending on flowering stage and year/day of harvest were carried out and published (Lawrence, 2007; Felklová et al., 1981; Neugebauerová \& Kafková, 2012). The aim of this study is to quantify the content of phenolic compounds in leaves of different Mentha species during a 4-year period.

\section{MATERIAL AND METHODS}

\section{Plant material}

The plants [M. × piperita cv. 'Perpeta' (MP), M. spicata subsp. spicata (MS), M. spicata var. crispa (MSC), M. $\times$ villosa $\mathrm{cv}$. 'Snežná' (MV), M. longifolia ssp. longifolia (ML), M. longifolia var. lavanduliodora (MLL)] were cultivated at the climate conditions of South-West Slovakia, in the Medicinal Plants Garden, Faculty of Pharmacy in Bratislava. Cultures were planted on a light sand-loam soil in a sunny location. The leaves were harvested in June/July, in the plant flowering phase on sunny days, morning at $11 \mathrm{am}$. The plants were dried at 32-35 ${ }^{\circ} \mathrm{C}$ and stored at room temperature. Voucher specimens were deposited at the Department of Pharmacognosy and Botany, Faculty of Pharmacy, Comenius University in Bratislava. We analysed the 1- to 4-year-old material at the same time.

\section{Secondary metabolites quantification}

Phenolic compounds were determined in dry leaves using spectrophotometric methods of the European Pharmacopoeia (Ph. Eur. 7, 2011).

\section{Total hydroxycinnamic derivatives (THD, Arnow's assay)} THD content was quantified using a colorimetric method with the Arnow's reagent at $505 \mathrm{~nm}$ (Spectrophotometer Genesys 6, Thermo Electron Corp. UK). The THD percentage was calculated with reference to the dried drug and expressed as rosmarinic acid.

\section{Flavonoids}

Total flavonoids content was quantified by a spectrophotometric method using aluminium chloride (Spectrophotometer Genesys 6, UK). The percentage was calculated using the external standard method (calibration curve at $392 \mathrm{~nm}$ ) with reference to the dried drug and expressed as luteolin-7-O-glucoside $(\lambda=392 \mathrm{~nm})$ and quercetin $(\lambda=420)$.

\section{Total polyphenols and tannins}

Total polyphenols content was quantified using a colorimetric method with Folin-Ciocalteu's reagent at 760 nm (Spectrophotometer Genesys 6, UK). Tannins content was quantified using the pharmacopoeial hide-powder method. The percentage was calculated with reference to the dried drug and expressed as rosmarinic acid.

Measurements were performed in triplicate at least.

\section{RESULTS AND DISCUSSION}

From a commercial point of view, the most famous mint is peppermint, which is the reason why this species was the frequent subject of research. Mentha $\times$ piperita is industrially cultivated worldwide. However, it is kept at one locality for 3-4 years only, as later, it gives a small yield of leaves and essential oil and becomes overgrown with weeds. Considering the length of cultivation at the same place, mints were assessed particularly for the essential oil content and quality (Telci \& Shahbaz, 2005; Vaverková et al., 2009), but there are not similar investigations of other secondary metabolites.

In our study, we examined the contents of phenolic compounds of different Mentha species. For the quantification experiments, we selected our domestic cultivar Mentha $\times$ piperita cv. 'Perpeta' and M. spicata, in spite of their high susceptibility to contamination by mint rust (Puccinia menthae), which can completely destroy an entire crop of mint in the second vegetation year already. Therefore, we paid special attention to select healthy plant material only. When comparing the quality of the leaves of plants of different age (1-4 years), the analyses were done after 6 months of storage. Furthermore, the content of phenolic compounds was compared after 1-4 years of storage.

We suggest that the losses of phenolic compounds caused by storage (1-4 years) will be minimal. As it was presented in available literature already, the decrease of phenolic compounds in Lamiaceae plants should be minimal, provided correct storage conditions. The decrease of the chosen polar compounds (e.g. tannins) after 3 years storage was about $5 \%$ only (Murko et al., 1974).

The loss on drying of the investigated Mentha taxa ranged from 8 to $10 \%$, which corresponds to the requirements of the European Pharmacopoeia for leaves drugs (Ph. Eur. 7, 2011). Ph. Eur. 7 requires expressing the content of phenolic compounds in dried drugs. For mints (peppermint), the pharmacopoeias prescribe essential oil quantification, but it is known that plants belonging to the family Lamiaceae subfamily Nepetoideae are, in addition to the essential oil, rich in phenolic constituents with valuable antioxidant activity. The most prominent group of phenolics are phenylpropanoic acid (hydroxycinnamic derivatives), in particular, rosmarinic acid (Petersen \& Simmonds, 2003).

Lamaison et al. (1991) described the determination of THD in different French Mentha species (3.1-6.5\%) using Arnow's reagent. THD content expressed as rosmarinic acid for $M$. $\times$ piperita was $6.1 \%$, M. longifolia $5.1 \%$ and $M$. spicata $6.5 \%$. The species $M . \times$ villosa was not included to their study. When monitoring the contents of phenolics in 1- up to 4-year-old plants, the highest content of THD was recorded in leaves of $M$. $\times$ piperita $\mathrm{cv}^{\prime}$ 'Perpeta' (from $7.13 \%$ to $11.32 \%$ ) with the height in $3^{\text {rd }}$ year. In other investigated samples, we detected the highest content of THD in $4^{\text {th }}$ year. In other investigated species, the highest content of THD was recorded in the $4^{\text {th }}$ year. In general, we can conclude that the content of THD in 


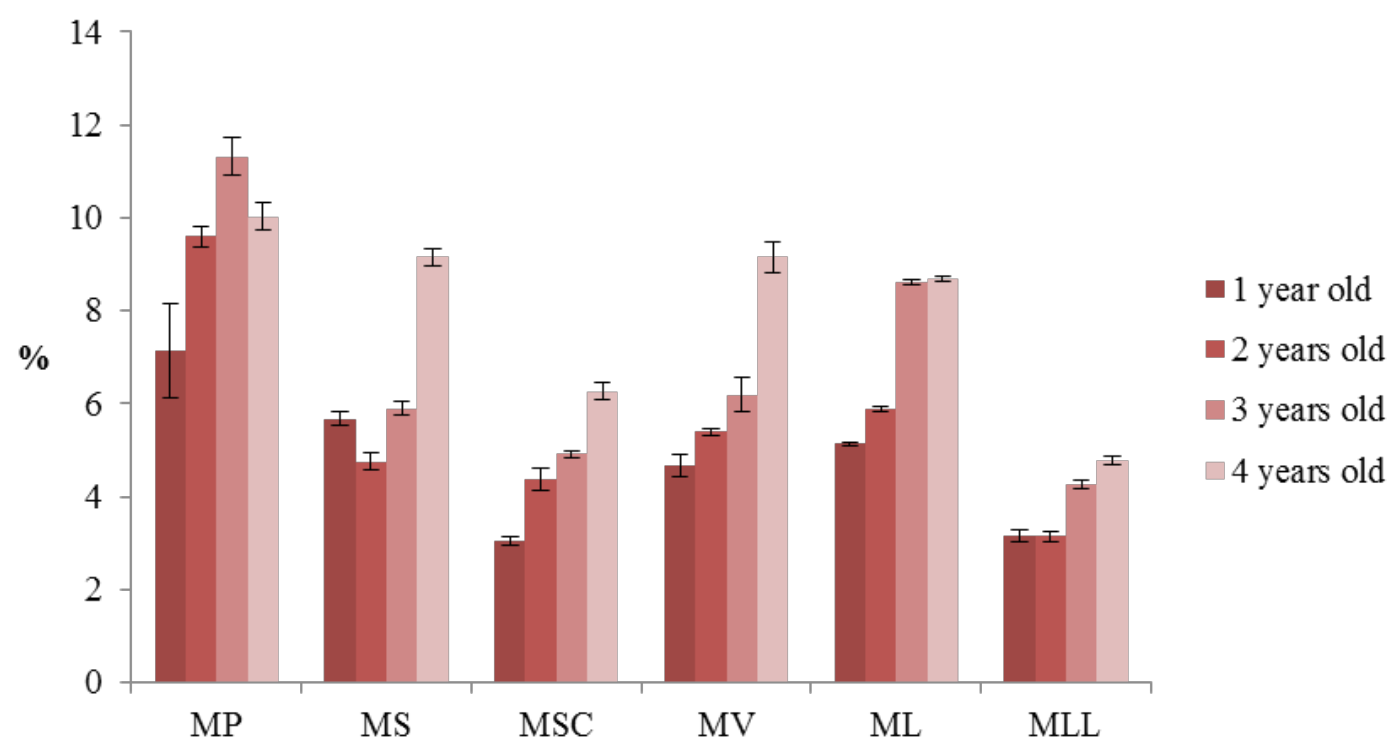

Figure 1. THD expressed as rosmarinic acid $(\lambda=505 \mathrm{~nm})$ in dry leaves of 1 - to 4-year-old mints. Values are presented as means \pm standard deviation. $M P=M . \times$ piperita cv. 'Perpeta', MS = M. spicata, MSC $=$ M. spicata var. crispa, $M V=M . \times$ villosa cv. 'Snežná,' $M L=M$. longifolia, $M L L=M$. longifolia ssp. Lavanduliodora, $T H D=$ total hydroxycinnamic derivatives

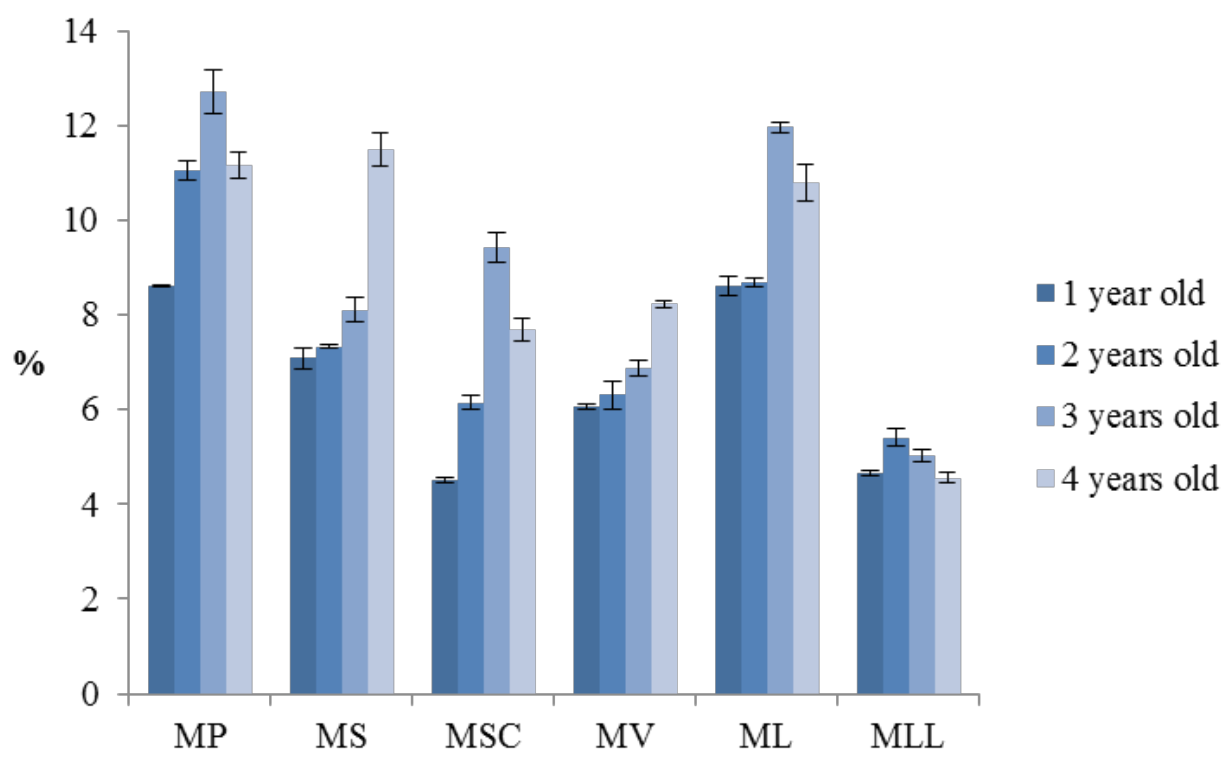

Figure 2. Total polyphenols expressed as rosmarinic acid $(\lambda=760 \mathrm{~nm})$ in dry leaves of 1- to 4-year-old mints. Values are presented as means \pm standard deviation. $M P=M . \times$ piperita $c v$. 'Perpeta', $M S=M$. spicata, $M S C=M$. spicata var. crispa, $M V=M . \times$ villosa cv. 'Snežná', $M L=$ M. longifolia, $M L L=$ M. longifolia ssp. lavanduliodora

Mentha species is higher in older growth, $3^{\text {rd }}$ and $4^{\text {th }}$ year of vegetation (Fig. 1).

The contents of phenolic compounds in drugs are commonly determined using Folin-Ciocalteu reagent. By this method with hide powder could be determined the content of tannins as well. Tannins in Lamiaceae family represent a special group of polyphenols, which named 'Lamiaceae tannins'. It is due to their chemical structure, esters, where the glycoside part is replaced by polyhydroxy acid. The European Pharmacopoeia requires expressing polyphenols and tannins as pyrogallol. However, we expressed them as rosmarinic acid, the most abundant polyphenol compound in mints (Figs. 2 and 3).

The determination of total polyphenols and tannins resemble results of THD determination. The highest content of total polyphenols was detected in 3-year-old $M$. $\times$ piperita cv.'Perpeta' (12.74\%) and the highest content of tannins in 4-year-old peppermint. The content of total polyphenols in M. longifolia and M. spicata var. crispa was highest in $3^{\text {rd }}$ 


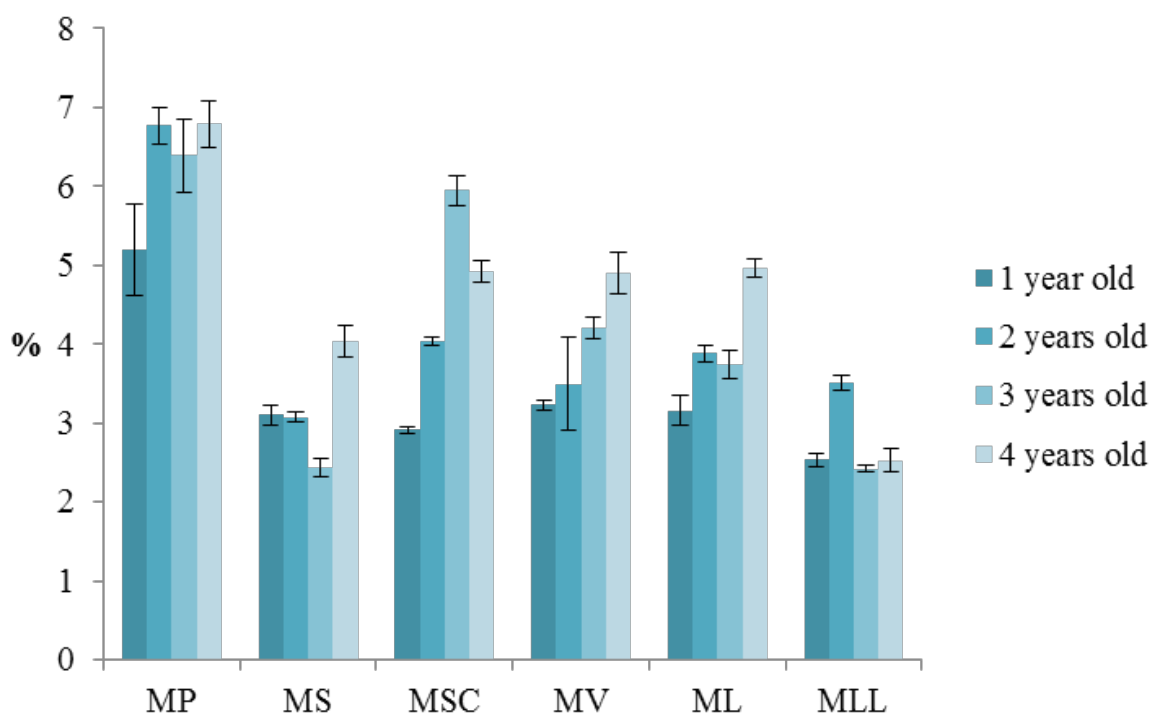

Figure 3. Tannins expressed as rosmarinic acid $(\lambda=760 \mathrm{~nm})$ in dry leaves of 1- to 4-year-old mints. Values are presented as means \pm standard deviation. $M P=M . \times$ piperita cv. 'Perpeta', $M S=$ M. spicata, $M S C=M$. spicata var. crispa, $M V=M . \times v i l l o s a c v$. 'Snežná, $M L=M$. longifolia, $M L L=M$. longifolia ssp. lavanduliodora

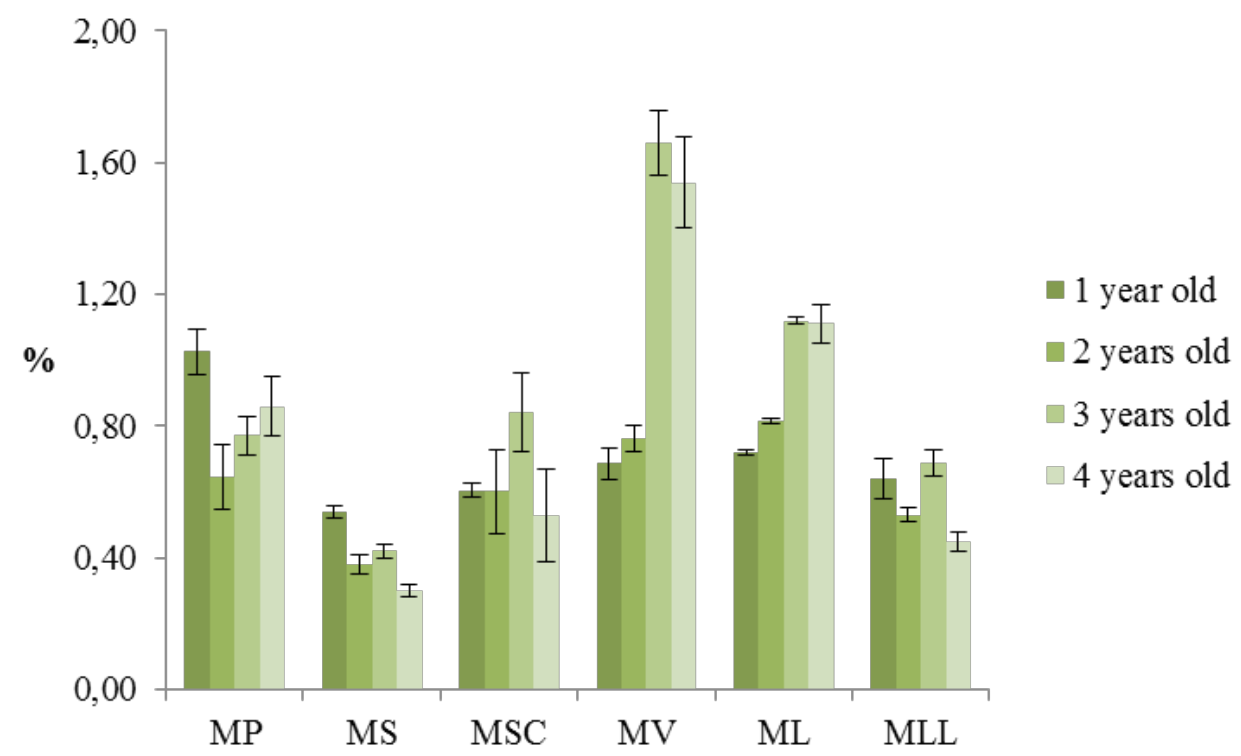

Figure 4. Total flavonoids [\%] expressed as luteolin-7-O-glucoside $(\lambda=392 \mathrm{~nm})$ in dry leaves of 1-to 4-year-old mints. Values are presented as means \pm standard deviation. $M P=M . \times$ piperita $c v$. 'Perpeta', MS $=$ M. spicata, MSC $=$ M. spicata var. crispa, $M V$ $=$ M. $\times$ villosa cv. 'Snežná,' $M L=M$. longifolia, $M L L=$ M. longifolia ssp. lavanduliodora

vegetation year (11.98\% and 9.44\%, respectively). M. spicata and $M . \times$ villosa cv. 'Snežná' have shown the highest content of polyphenols in $4^{\text {th }}$ year of vegetation (11.53 and $8.25 \%$, respectively). Only $M$. longifolia var. lavanduliodora had higher content of polyphenols in first 2 years of vegetation. Very similar results brought the determination of tannins (Fig. 3). With one exception ( $M$. longifolia var. lavanduliodora), we shall also conclude that the content of polyphenols and tannins increases with the plant age.

Flavonoids were examined using the method with aluminium chloride. From the drug, they were extracted with acetone.
Aglycones were shaken out into ethyl acetate. Two different types of flavonoids could be detected in mints. First group represents flavonoids that after reaction with $\mathrm{AICl}_{3}$ absorb UV around $392 \mathrm{~nm}$ (luteolin type) and second group flavonoids with maximum absorbance at $\lambda=420 \mathrm{~nm}$ (quercetin type). The highest contents of flavonoids expressed as luteolin-7-Oglycoside (Fig. 4) in M. spicata var. crispa, M. $\times$ villosa and $M$. longifolia and $M$. longifolia var. lavanduliodora were detected in 3-year-old plants $(0.84 ; 1.66 ; 2.11$ and $0.69 \%$, respectively). M. $\times$ piperita and $M$. spicata have the highest content of flavonoids of luteolin type in the $1^{\text {st }}$ year. 


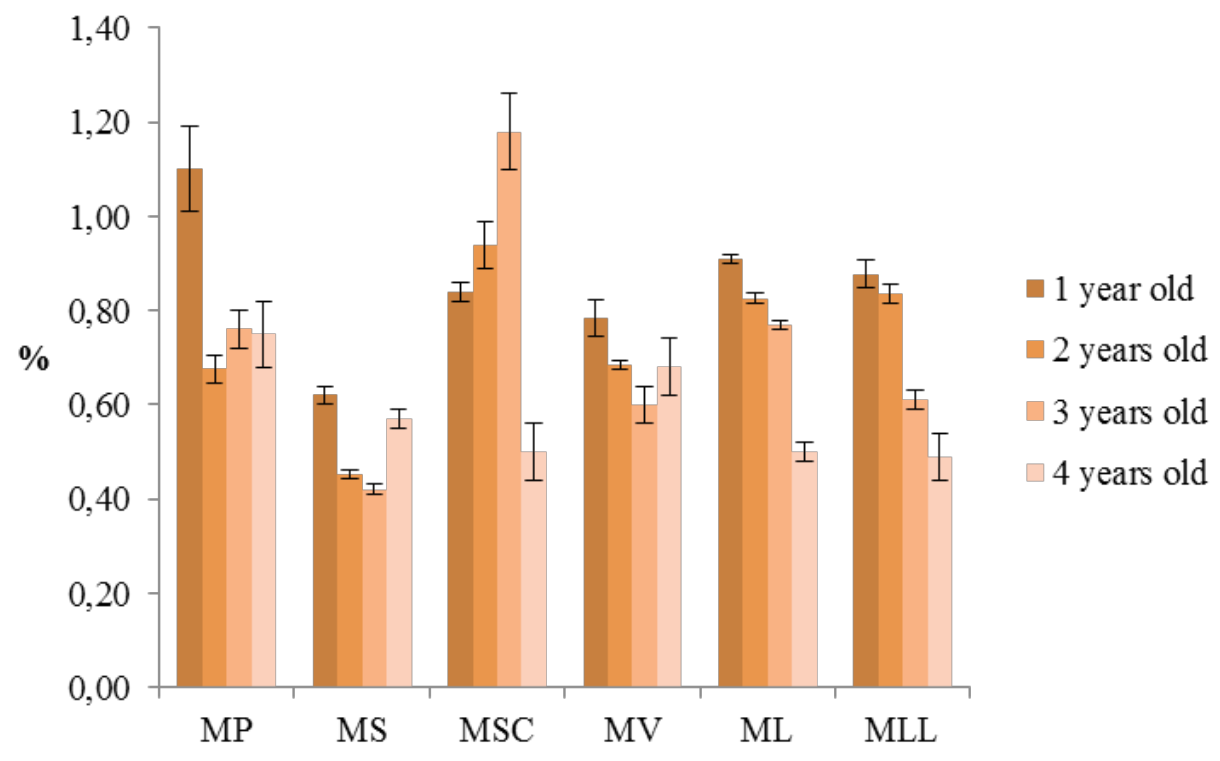

Figure 5. Total flavonoids [\%] expressed as quercetin $(\lambda=420 \mathrm{~nm})$ in dry leaves of 1- to 4-year-old mints. Values are presented as means \pm standard deviation. $M P=M . \times$ piperita $c v$. 'Perpeta', $M S=M$. spicata, $M S C=M$. spicata var. $c r i s p a, M V=M . \times$ villosa cv. 'Snežná', $M L=$ M. longifolia, $M L L=$ M. longifolia ssp. lavanduliodora

The highest content of flavonoids expressed as quercetin (Fig. 5) was recorded in 3-year-old plants only in M. spicata var. crispa (1.18\%). In other investigated species, we detected highest levels of flavonoids express as quercetin in the $1^{\text {st }}$ year of vegetation. Anyway, the differences in flavonoid levels could be better explained by the influence of external factors (long-term weather before harvesting time, intensity of sunlight, pathogens and time of the day of harvesting). As mentioned above, only little is known about differences in secondary metabolites content in mints depending on the age of plant. In the period of 4 years (1998-2001), Telci and Shabhaz (2005) investigated the content and composition of essential oil of Mentha $\times$ piperita L., from Turkey (Gaziantep and Adana). The highest content of essential oil was recorded in the $2^{\text {nd }}$ harvest of $2^{\text {nd }}$ year $(2.8 \%)$, while the minimal levels were detected in the $1^{\text {st }}$ harvest of $3^{\text {rd }}$ year $(1.7$ and $1.6 \%$, respectively) (Telci \& Shabhaz, 2005).
We suggest that each mint prefers different growth conditions that can influence the contents of secondary metabolites. Anyway, the age of plant could also be a limiting factor for the drug quality.

\section{CONCLUSION}

In general, it is recommended to cultivate mint at one place for 2-3 years only, but no longer than 4 years. Our results based on determination of secondary metabolites variation during 4-year period refer to high level of active phenolic compounds, particularly in 3- and 4-year-old plants. We suggest that the decrease of essential oil in $4^{\text {th }}$ year is not matched by decrease of phenolic compounds, quite the contrary in some cases, the content of phenolics increases.

\section{References}

[1] Duke JA, Bogenschultz-Godwin MJ, Ducellier J, Duke PAK. Handbook of medicinal herbs. $2^{\text {nd }}$ edition, CRC Press Boca Raton; 2002:562-4.

[2] European Pharmacopoeia, $7^{\text {th }}$ Edition (Ph. Eur. 7), Council of Europe. Strasbourg; 2011.

[3] Felklová M, Lukeš V, Motl O. 1981. Effects of drying on quality and quantity of essential oil from peppermint (Mentha piperita (L.) Huds.) attacked by rust (Puccinia menthae Pers.). Farm Obzor. 1981;12:585-93. (in Slovak).

[4] Fialová S, Tekel'ová D, Mrlianová M, Grančai D. The determination of phenolics compounds and antioxidant activity of mints and balms cultivated in Slovakia. Acta Fac Pharm Univ Comen. LV, 2008: 96-102.

[5] Fialová S, Tekel'ová D, Grančai D. The content of phenolic compounds in underground and aerial parts of different Mentha species. Acta Fac Pharm Univ Comen. LIX, 2012 (1): 30-38.

[6] Gulluce M. et al. Antimicrobial and antioxidant properties of the essential oils and methanol extract from Mentha longifolia L. ssp. longifolia. Food Chem. 2007;103:1449-56.

[7] Koštálová D, Fialová S, Račková L. Phytotherapy in Current Medicine: Osveta Martin; 2012. (in Slovak). 
[8] Lamaison JL, Petitjean-Freytet C, Duband F, Carnat A. Rosmarinic acid content and the antioxidant activity in french Lamiaceae. Fitoterapia. 1991; 62 (2):166-70.

[9] Lawrence BM. Mint. The genus Mentha. Medical and Aromatic Plants - Industrial Profiles. Boca Raton: CRC Press; 2007.

[10] Mckay DL, Blumberg JB. A review of the bioactivity and potential health benefits of peppermint tea (Mentha piperita L.). Phytother Res 2006;20(8):619-33.

[11] Murko D., Ramic S, Kekic M. Tannins of Salvia officinalis and their changes during storage. Planta Med. 1974;25:295-300. (in German).

[12] Neugebauerová J, Kaffková K. Variability of essential oil content of Mentha L. taxa. Acta Univ Agric et Silvic Mendel Brun 2012;60:187-90.
[13] Petersen M. Rosmarinic acid: new aspects. Phytochemistry Reviews. 2013;12:207-227.

[14] Telci I., Shahbaz N. Determination of Agronomic and Essential Oil Properties of Peppermint (Mentha piperita L.) in Various Ages of Plantation. Journal of Agronomy 2005;4(2):103-8.

[15] Vaverková Š, Mistríková I, Hollá M. Qualitative properties of Mentha $\times$ piperita (L.) after application of the fungicide Hattrick DP-50. Plant Soil Environment. 2009;55(10):454-9. 